Article

\title{
Exploring Cultivation Path of Building Information Modelling in China: An Analysis from the Perspective of an Innovation Ecosystem
}

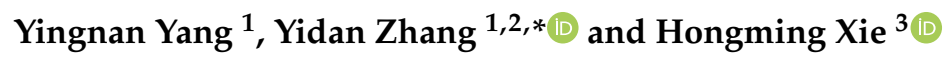 \\ 1 College of Civil Engineering and Architecture, Zhejiang University, Hangzhou 310058, China; \\ yyn@zju.edu.cn \\ 2 Department of Civil Engineering, The University of Hong Kong, Hong Kong 999077, China \\ 3 School of Management, Guangzhou University, Guangzhou 510006, China; hmxie@gzhu.edu.cn \\ * Correspondence: 3130102512@zju.edu.cn or ydzhang@connect.hku.hk; Tel.: +86-157-0007-7750
}

Received: 15 July 2020; Accepted: 21 August 2020; Published: 25 August 2020

\begin{abstract}
Ecosystem theory provides a new perspective for studying the development of the architecture engineering and construction (AEC) industry in the age of information and communication technology (ICT). As an extremely ICT innovation, building information modelling (BIM) not only brings technical benefits to the AEC industry, but changes the innovation paradigm of the AEC industry towards an innovation ecosystem, which improve productivity and sustainability throughout the project life cycle. This article contributes to innovation ecosystem theory by exploring the structure of the BIM ecosystem and deriving its cultivation path. Then, as the leading city in China for developing BIM technologies, Shanghai was selected as the case study to elaborate on the cultivation path of the BIM ecosystem. The results indicate that three layers identified in the structure contribute to the understanding of the boundaries, units, and analytical focus of the BIM ecosystem, with the BIM platform being the core layer. This topology structure, with the BIM platform as the hub, promotes interdependency and symbiosis among participants in the cultivation of the BIM ecosystem, supporting the birth, expansion, maturity, re-innovation (or extinction), and sustainable development of the BIM ecosystem. This research complements and extends literature on the BIM ecosystem, and provides implications as to the construction, cultivation, and sustainability of BIM ecosystems for emerging economy firms.
\end{abstract}

Keywords: architecture engineering and construction (AEC) industry; building information modelling (BIM); ecosystem; cultivation; sustainability

\section{Introduction}

The architecture, engineering, and construction (AEC) industry, as one of the major contributors to both environmental and socioeconomic issues, is vital in achieving sustainable development [1]. There is an enormous demand for infrastructure construction in developing countries in order to sustain an accelerated economic growth, which comes at a very high cost to the environment [2]. To alleviate the environmental burden and low productivity associated with conventional construction, the recent global trend is to promote modular construction [3-6]. As mentioned in the SmartMarket report of 2011 [7], the reemergence of modular constructions as a "new" trend can be tied to the adoption of a new technology-building information modelling (BIM). The main reason is that BIM has allowed implementing manufacturing concepts such as lean design and modularization into the AEC industry [8]. Also, BIM is a technological innovation that can drive the transition to sustainability in the construction sector $[9,10]$. This means that BIM needs to be integrated into the whole lifecycle 
of construction projects. Consequently, BIM contributes to the sustainable development of the AEC industry from the economic, social, and environmental perspectives, but also the organizational one [11].

With the introduction of BIM, the innovation paradigm of the construction industry has been changing and upgrading towards an ecological and organic innovation ecosystem [12]. The sustainable development of the AEC industry is not only derived from technological change or policy support, but also depends on the imbedded innovation ecosystem. As an innovation throughout the life cycle of a project, BIM requires technical, capital, process, organizational, and cultural support. The interaction of these different aspects builds a BIM ecosystem. The ecosystem concept has been adopted as a unit of analysis to capture the structural and functional interrelationships between various actors of the AEC industry [12]. However, the theorizing of a BIM-based innovation ecosystem is still in its infancy and in-depth studies from emerging economy are insufficient.

As the largest AEC market in the world, China is struggling to drive an industrial transformation from a traditional extensive pattern to sustainable development [13]. BIM has become a key solution to various challenges of implementing sustainable construction phases [14]. In this context, the objective of this article was to analyze the formation and evolution of BIM in China from the perspective of an innovation ecosystem. More specifically, this paper sought to examine the basic structure and the cultivation of China's BIM ecosystem. A good understanding of the basic structure is the basis for further BIM ecosystem research. Furthermore, the research on the BIM ecosystem seeks to discover how the communities of government, enterprises, and so on practice symbiotic innovation to nurture the BIM ecosystem to achieve sustainable development of the AEC industry. This study took the BIM ecosystem of Shanghai as the object of case study and tried to discuss how the BIM ecosystem is cultivated in China. The cultivation path of the BIM ecosystem in China will provide valuable references for other countries that are applying or preparing to adopt BIM technology.

After this introduction, the rest of the paper is structured as follows: Section 2 provides the literature review of the BIM ecosystem, followed by the research design and methods in Section 3. Section 4 discusses the structure of the BIM ecosystem, and Section 5 discusses cultivation of BIM ecosystems. Section 6 presents the theoretical and practical implications of this paper, and Section 7 concludes the paper by discussing the limitations and suggestions for future research.

\section{The Literature Review of the BIM Ecosystem}

Prior to this paper, a search study of BIM literature using knowledge-mapping techniques was conducted, and the results are presented in Yang (2017) [15]. In order to ensure that the selected papers are of reference value, we set the inclusion criteria for the search. For example, only journal papers were selected, and they were required to be in English. The search rule for BIM-related literature was ("BIM" OR "building information modeling" OR "building information modelling" OR "building information model"), the search rule for innovation ecosystem literature was ("innovation" OR "construction innovation" OR "innovation ecosystem"), and the search rule for BIM ecosystem literature was ("ecosystem") AND ("BIM" OR "building information modeling" OR "building information modelling" OR "building information model"). As shown in Table 1, 20 journals with great influence in the field of civil engineering and innovation ecosystem were selected, which were highly ranked by construction management and strategic management researchers (e.g., [16,17]). More than 1000 papers on BIM from 2000 to 2019 were selected and analyzed to explore the current research focus and future research directions. It is noteworthy that past and present research has focused too much on BIM technology itself, neglecting its socioeconomic and organizational issues. However, the interdisciplinary nature of BIM, with its technical and nontechnical potentials and challenges, requires a systematic analysis to understand this paradigm shift in the AEC industry [15]. 
Table 1. Information of selected journals.

\begin{tabular}{l} 
Journal Name \\
\hline Automation in Construction \\
International Journal of Project Management \\
Journal of Construction Engineering and Management \\
Construction Management and Economics \\
Journal of Management in Engineering \\
Construction and Architectural Management \\
Journal of Cleaner Production \\
Journal of Computing in Civil Engineering \\
International Journal of Construction Management \\
Advanced Engineering Informatics \\
Harvard Business Review \\
Strategic Management Journal \\
Management Decision \\
Journal of Management \\
Academy of Management Perspectives \\
Construction Innovation \\
Architectural Engineering and Design Management \\
Journal of Professional Issues in Engineering Education and Practice \\
International Journal of Technology Management \\
Journal of Product Innovation Management
\end{tabular}

BIM has been increasingly adopted in the AEC industry since its inception in the 1970s, particularly in the last few years $[18,19]$. As an important technology to promote the sustainable development of the AEC industry, the BIM implementation has become a focus of study by scholars from different countries in recent years, particularly with regard to barriers to the implementation of BIM (e.g., Doumbouya et al. [20]; Walasek and Barszcz [21]), potential problems (e.g., Becerik-Gerber and Kensek [2]), critical success factors (e.g., Tsai et al. [22]) and case studies intending to draw lessons and experience from the implementation of BIM (e.g., Eadie et al. [23]; Luth et al. [24]; Cao et al. [25]).

By considering the possible gap among technical feasibility, potential value, and practical adoption, increasing research interests and efforts were presented to examine the degree by which BIM is currently adopted through the life cycle of construction projects in different countries or regions [18-20]. These studies offered a better understanding of the current status, problems, and constraints encountered in BIM implementation. With the implementation of BIM, some research studies (e.g., Aksenova et al. [12]; Singh et al. [26]) noted that the innovation paradigm of the AEC industry has been changing and upgrading towards an ecological and organic innovation ecosystem.

In order to study BIM implementation from the perspective of an innovation ecosystem, the research papers related to innovation and innovation ecosystems were further collected and reviewed. The concept of ecosystem was first introduced by Moore [27] to social science, as an approach to viewing firms, not as a part of an industry, but as an ecosystem where interdependent complementary actors cooperate, compete, and co-evolve around a new innovation to achieve competitive advantages [28,29]. Pulkka et al. [30] introduced the concept of the ecosystem in the context of the construction industry and suggested that the ecosystem concept is applicable and offers a useful analytical lens for understanding value creation in the construction industry. With the advancement of industrialization and informatization, BIM is no longer simply understood as a software or technology, but rather the innovation of the AEC industry, affecting all aspects of the industry [25]. Therefore, following Moore [27,31], Singh [32] defined the BIM ecosystem as the network of interacting technologies, processes, policies, and organizations that collectively determine the development and evolution of BIM-related products and services. Some studies (e.g., Pulkka et al. [24]; Jiang et al. [26]) have adopted the ecosystem concept to understand the imbedded system formed by BIM-related products, processes, and stakeholders. Based on the theory of ecology, Liu, Zeng, and Xu [27] proposed a theoretical framework for the BIM ecosystem, making a preliminary understanding of the BIM ecosystem possible. 
The term "BIM ecosystem" is used to identify the economic, political, technical, and organizational systems involved in BIM, through which they can cultivate, maintain, and support an environment conducive to the operation of BIM. Through long-term observation of the development and application of BIM in Finland, Aksenova et al. [12] explored the Finnish innovation journey by capturing and recording historical sequence of key events and actors in the process and elaborated on the reasons why the BIM ecosystem in Finland did not evolve as expected. Although the BIM ecosystem has received much attention from academics in recent years, the theoretical background is still insufficient in the basic structure and cultivation of the BIM ecosystem from an evolutionary perspective.

Existing theoretical research of innovation ecosystem provided significant inspiration and foundation for this study. Tomás et al. [33] identified that not all innovation ecosystems have the same architectural models or internal collaboration, and existing research rarely deconstructs an ecosystem of innovation and examines its structure. This article contributes to innovation ecosystem theory by exploring the structure of the BIM ecosystem. Compared with developed countries such as the USA, the application of BIM in China is still in its infancy [34], and the AEC industry has not yet formed a self-organizing and self-updating ecosystem. However, the ecological phenomenon appearing in this process has attracted the attention of scholars [12,26,32,35]. Therefore, studying the structure and cultivation path of China's BIM ecosystem is more valuable for promoting informatization of the AEC industry in an emerging economy.

\section{Research Design and Methods}

In terms of the research design, this study took the following research process: literature review, draft design and data collection, data analysis and case study (see Figure 1). First, the study started with literature search which was targeted to confirm the research problems of this paper. Secondly, to address the research objectives, a comprehensive data collection and processing was used. The research data consist of literature review, interviews, marketing data, and policy documents. Thirdly, based on the theory of innovation ecosystem, data were analyzed to explore the basic structure and cultivation path of the BIM ecosystem in China. Finally, as the leading city in China for implementing BIM technologies, Shanghai was selected as the case study to elaborate on the cultivation path of the BIM ecosystem.

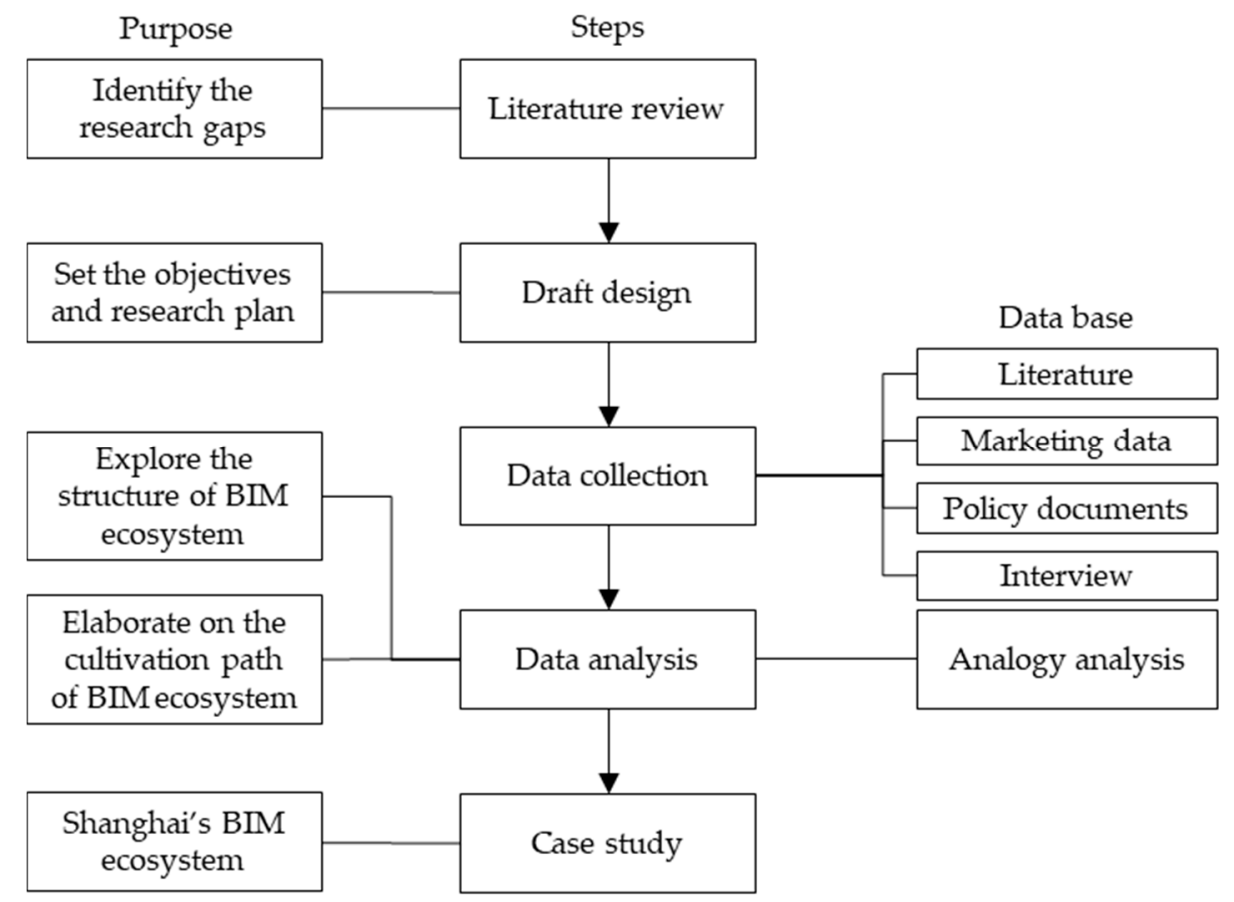

Figure 1. Research flow. 


\subsection{Interview}

In order to get the whole picture of the BIM practices, the interview outlines were designed. The study team conducted formal and informal in-depth interviews with government actors, public agencies, industry, and academics. A semi-structured interview schedule was adopted to collect information by personal interview about the application of BIM, especially in Shanghai. Questions were asked relating to describing the key events, the technological changes, the marketing status, the effects of policies which were likely to affect the BIM practices. McCracken [36] long interview techniques were used to guide the interview and to provide focus using a series of open-ended questions pertaining to the BIM practices in construction projects. The average duration of each interview was one hour. Interviews were recorded and transcribed accordingly. Finally, based on the interview records and multiple data sources collected through the government units, Internet, published papers, and BIM projects reports, the reliable data were used to identify the main players, symbiotic relationships, the socioeconomic environment, and the evolution process of the BIM ecosystem.

Twenty interviews (over 30 hours) were conducted in 2019 and 2020, with representatives distributed among seven key stakeholder and end-user groups: (1) government agency; (2) research institution; (3) property owner; (4) design company; (5) construction company; (6) consulting company; and (7) software company. Table 2 lists the profiles of the interviewees.

Table 2. The profiles of the interviewees.

\begin{tabular}{ccc}
\hline Interviewee & Average Years of Using BIM & Number of Interviews \\
\hline government agency & about 5 years & 4 \\
research institution & $>10$ years & 4 \\
owner & about 5 years & 3 \\
design company & about 8 years & 3 \\
construction company & about 8 years & 4 \\
consulting company & $>10$ years & 2 \\
software company & $>10$ years & 4 \\
\hline
\end{tabular}

\subsection{Marketing Data}

In order to understand the current status of BIM applications in Shanghai, market reports provided a great amount of detailed information about BIM technology, policy, enterprises, projects, and so on, especially "Shanghai BIM technology Application \& Development Reports" between 2016 and 2019 [37-40] issued by the Shanghai Municipal Commission of Housing Urban-Rural Development and Management and the Shanghai BIM Technology Application Joint Conference Office. In addition, relevant data on the AEC industry were collected from professional networks. Finally, these data on BIM trends and market share were combined in time series.

\subsection{Policy Document}

In order to understand the evolution process of the BIM ecosystem, this article collected the BIM-related documents issued since 2011. The starting point for China to promote the application of BIM from the policy perspective is 2011, when the 2011-2015 Outline for the Information Development of the Construction industry [41] was issued by the Ministry of Housing and Urban-Rural Development (MOHURD). Subsequently, the MOHURD successively issued a number of important documents to promote the application and development of BIM technology. Around 2014, the number of policies related to building information technology surged. Provincial and municipal entities have issued BIM promotion and application documents in response to the requirements of national and industrial building informatization in accordance with their actual conditions. As for the establishment of the BIM standard system, the plan of developing and revising standards for engineering and construction issued by the MOHURD in 2012 announced that 5 national BIM-related standards would be formulated: Unified standard for building information model application [42], Standard for classification and 
coding of building information model [43], Standard for storage of building information model [44], Application standard for manufacturing industry design information model [45], Standard for design delivery of building information modelling [46]. Subsequently, the Standard for building information modelling in construction [47] and the Presentation standard for building information modelling [48] were also included in the standard development plan in 2013 and 2014, respectively. Since the first national standard Unified standard for building information model application came out in 2016 [42], another four standards have been put into use successively, and the standard named Standard for storage of building information model [44] is under approval. Due to the slow setting progress of BIM-related standards at the national level, some provinces and cities, especially these areas with developed economies and highly developed construction industries, have issued regional BIM standards before the national ones in order to meet their own development needs and to guide the implementation of BIM technology in projects. In addition, the China BIM Union has also carried out the preparation of $21 \mathrm{P}$-BIM standards, which are based on the specialization in projects and play an important role as a complement to the BIM standard system.

\subsection{Case Study}

The potential advantage of a case study analysis is to gain a better understanding of "how" and "why" things happen. In single case study research, the opportunity to open a black box arises by looking at deeper causes of the phenomenon [49]. One key point of this paper is to discuss how Shanghai cultivates its BIM ecosystem. Also, the analytic generalization principle from cases to theory is suitable for exploring and explaining the research phenomena above [50].

This research selected Shanghai's BIM ecosystem as the case for the reason that it reflects the following three principles of case selection. First of all, the case selection takes into account both importance and representativeness. Shanghai is the leading region in China for developing BIM technologies and one of the first provincial governments to issue BIM policy in China. Secondly, the selection of research sample follows the principle of theoretical sampling. The choice of case is based on the need to fill existing theoretical gaps or develop new theories rather than statistical sampling [51]. The basic structure and the cultivation of the BIM ecosystem are important topics of academic concern. Existing theoretical research provides a foundation for the basic concepts of the BIM ecosystem. The research on Shanghai's BIM ecosystem tries to discover how the communities of the governments, enterprises, and other participants practice the symbiosis innovation to cultivate an BIM ecosystem for a resource-rich area. It helps to improve BIM ecosystems theory. Thirdly, the case selection should reflect the consistency principle of theory and research object [50]. The author team who attended the field surveys is deeply impressed by promotion from the Shanghai government and rapid growth of BIM projects. The data are relatively sufficient and integrated. Therefore, carrying out case studies grounded in the Shanghai context is urgently needed to provide both theoretical and practical insights for emerging markets.

\section{Structure of the BIM Ecosystem}

According to Taylor and Bernstein [52], BIM practice paradigms will evolve along a trajectory, from visualization, to coordination, to analysis, and finally to supply chain integration. This process also incorporates changes of the complex socioeconomic relationships among the technology, process, organization, built environment, and others [26,53]. It is necessary to analyze the structure of the BIM ecosystem as it is the basis for further research. Also, previous research can provide us with many insights for the construction of BIM structures. For example, Tansley [54] described natural ecosystem as a community of living organisms in conjunction with the nonliving components of their environment. Ron Adner [55] proposed a clear definition of the ecosystem construct through a structuralist approach and suggested the basic elements that describe the structure of ecosystems, namely actors, activities, locations, and the links between them. 
Based on the literature review, this article firstly conducted an analogy analysis between a BIM ecosystem and a natural ecosystem to identify the involved actors and activities (see Figure 2). In an information ecosystem, information producers, information consumers, and information decomposers are people or organizations that generate, utilize, and ultimately process information. Due to the unique nature of the AEC industry and the level of regional development, the current BIM ecosystem in China is project-based, involving a large number of participants. It includes not only owners, designers, contractors, material suppliers, and government officials, which come from the traditional AEC industry, but also the enterprises from the IT industry. Therefore, project stakeholders are identified as the key players in the BIM ecosystem. Based on their information activities, they can be divided into three categories: information producers, information consumers, and information decomposers (see Figure 2). The information producer (e.g., the design firm) creates the initial information and transmits it to the primary consumer (BIM platform) for storage and initial processing. When other consumers (e.g., other participants in the project) request information, the information is read from the BIM platform as needed. The updated information is then transmitted to the BIM platform for data storage and integration. Unlike a natural ecosystem, the roles of the players in a BIM ecosystem are not always fixed. The roles as producers, consumers, or decomposers depend on their functions in different information activities.

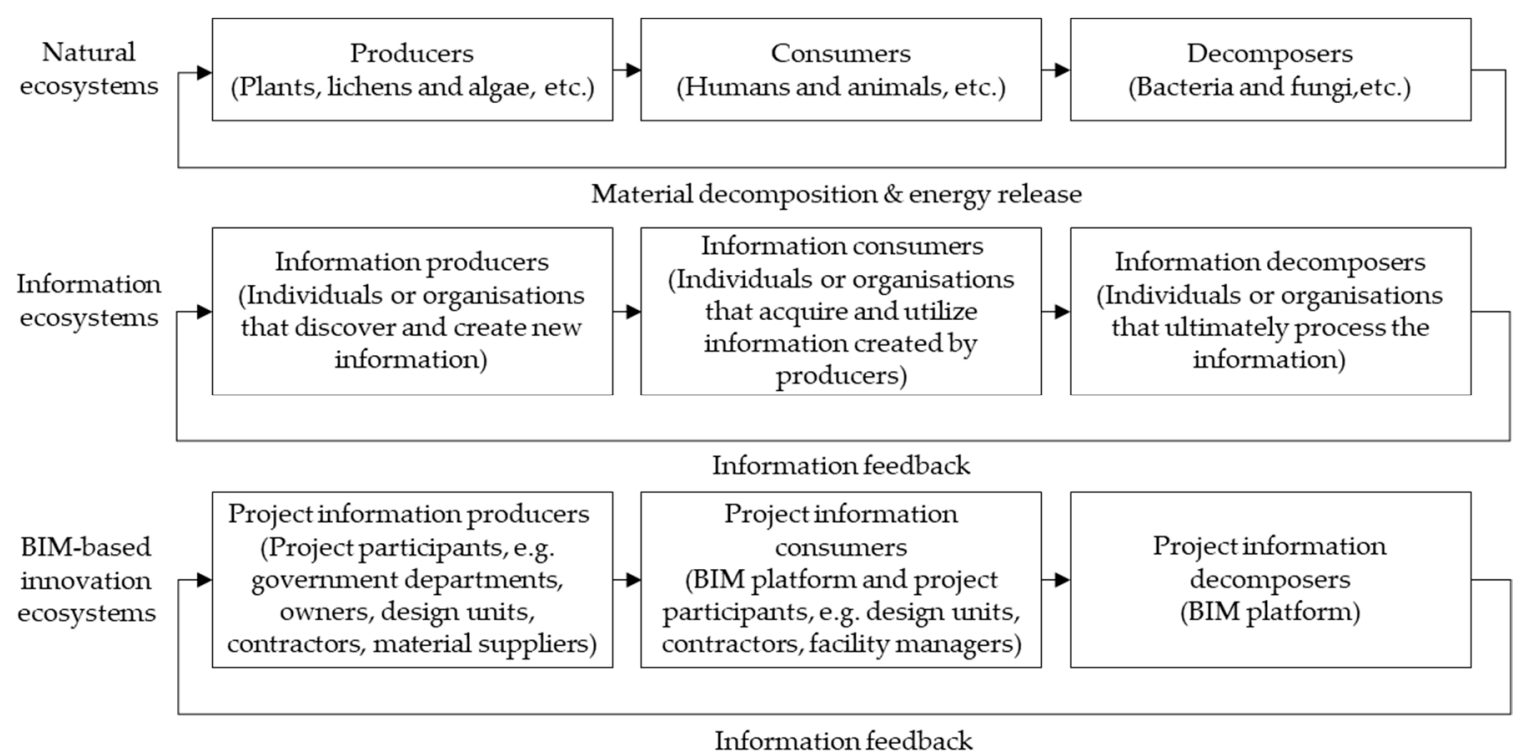

Figure 2. Comparison of natural ecosystems and a BIM ecosystem (biological components).

Singh [32] defined the BIM ecosystem as a network of interacting technologies, processes, policies, and organizations that collectively determine the development and evolution of BIM-related products and services. Based on this definition, Succar [56] and Succar and Kassem [57] identified the sub-domains and constituents that are specific to BIM ecosystems. Of these, technology, process, and policy are three interlocking fields of BIM activity, each of which is followed by two sub-domains (players and deliverables). Drawing on the literatures and interviews, we deconstructed the BIM ecosystem and examined its structure (see Figure 3). The BIM ecosystem can be described as three layers: the core layer, the middle layer, and the outermost layer. The core layer of the BIM ecosystem is the BIM platform, which consists of four main components, namely, databases, the IFC (Industry Foundation Class) engine, the Internet of Things, and big data analytics, to facilitate the information insertion, sharing, processing, and integration [58]. The scope of BIM is expanding from the intra-disciplinary collaboration to multi-disciplinary collaboration through a BIM-server that provides a platform for direct integration, storage, and exchange of data from multiple disciplines [57]. The middle layer represents the project participants in the supply chain, such as owners, consultants, designers, contractors, etc., interacting with each other through the BIM platform. They are the direct 
beneficiaries of the innovation ecosystem, forming a topology structure with the BIM platform as the hub. The outermost layer is the environment, which supports the collaboration of project participants in terms of technology, hardware device, policies, etc. [56]. As suggested by the interviewees, economic issues and standardization of BIM can be supplemented as supporting environments of the construction. The cost of BIM application hinders the intention of BIM adoption, so it is necessary to include the cost of BIM application in the budget and ensure it is paid to the general contractor at the beginning of the project. Also, new industry standards for BIM have been released in China in 2019. In addition, the biggest obstacle to BIM R\&D is the lack of funding. The economic benefits of R\&D will be reflected in engineering practices, but few companies are willing to pay for $R \& D$, especially private companies. The main reason is a large initial investment and a long payback period.

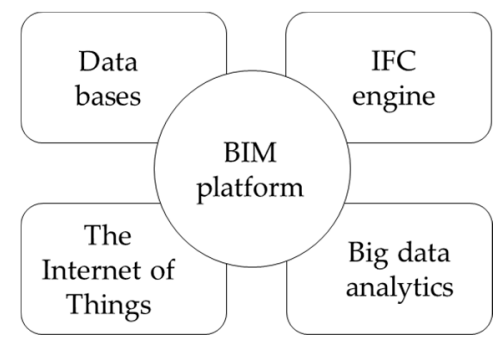

(a)

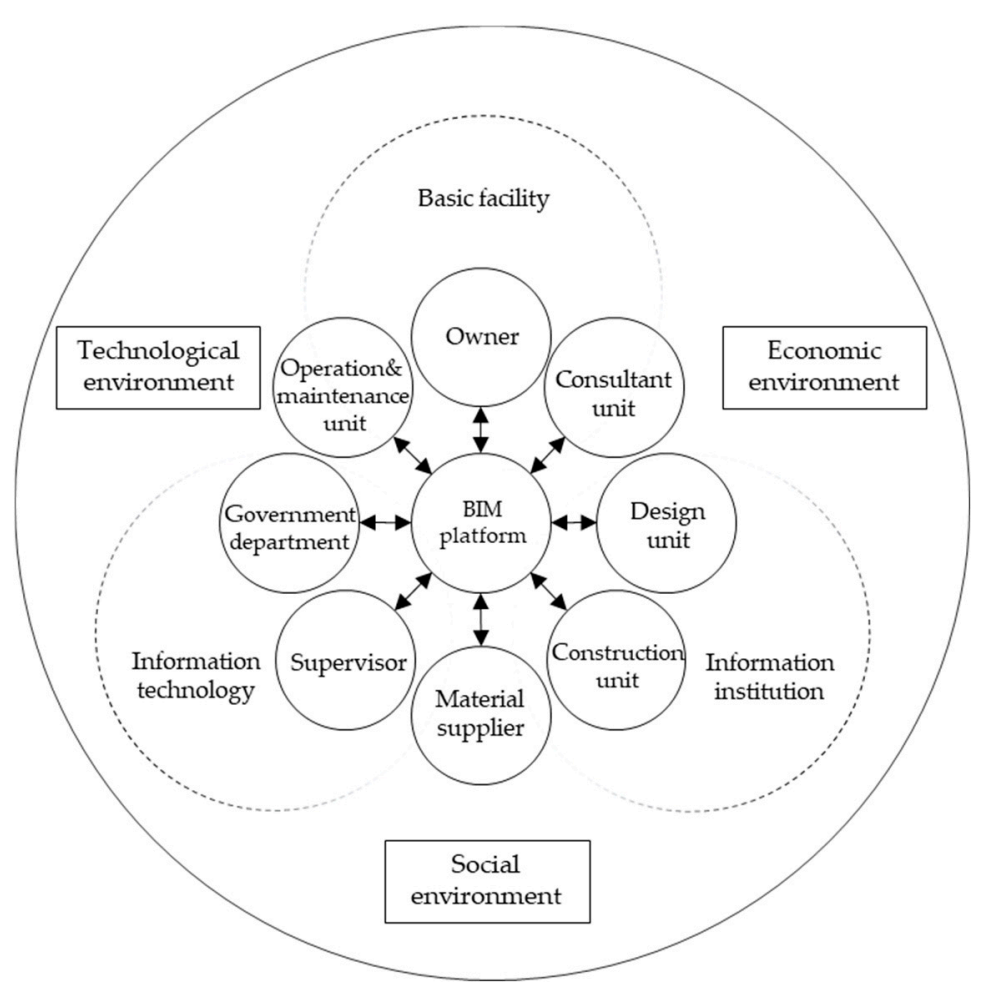

(b)

Figure 3. The basic structure of a BIM ecosystem: (a) core layer; (b) basic structure.

\section{Cultivation of BIM Ecosystems}

\subsection{Cultivation Path of BIM Ecosystems}

The AEC industry has a complex sociotechnical environment, with entangled power relationships between different stakeholders [59]. This leads to a complex organization, a fragmented structure of the construction sector, and project-based collaborations, posing critical challenges to change management 
and diffusion of construction innovation [60-63]. The BIM research team of Tsinghua University identified the tasks in the informatization process from the perspectives of the nation, industry, and enterprises [64]. Based on the ecosystem theory proposed by [31] and taking into account the unique nature of the AEC industry, the cultivation path of BIM ecosystems was derived, as shown in Figure 4. The cultivation path of BIM ecosystems consists of four stages: birth, expansion, maturity, re-innovation or extinction.

In the birth stage, the desire for product and service innovation inspired some pioneer enterprises to invest in R\&D of BIM technology. However, the number of such pioneer enterprises is small and is growing slowly. There are several reasons for this phenomenon: As a new innovation, the application of BIM requires enterprises to invest a lot of human, material, and financial resources to support R\&D and personnel training [65]. As indicated in the interviews, this requires the enterprises to have strategic vision and courage, because such a huge investment will not bring benefits to the enterprises in the short term; at the same time, lack of support from the market has also prevented some companies from participating. In the expansion stage, enterprises have begun to actively and passively participate in the development and application of BIM technology, gradually forming standardized market-oriented business. One of the salient features of this stage is the policy support from local governments, which greatly stimulated the enthusiasm of related enterprises, thereby fulfilling the potentials of BIM technology and regulating the operating process and market environment. Some new project delivery system, such as the integrated project delivery (IPD) as a natural companion to BIM, have also effectively eased the status of fragmentation and promoted the application of BIM technology [8]. In the maturity stage, the market is becoming stable and mature. Based on the ecosystem theory [31], as the BIM platform has been widely recognized, the status and roles of enterprises in the ecosystem begin to change due to their own innovation capabilities. For those pioneer enterprises that initiated R\&D of BIM technology at the early stage, the investment is starting to pay off. These enterprises are gradually becoming leaders in the competition and occupy the core position in the ecosystem. The pioneer enterprises dominate the market, and those that cannot keep up with the trend of building informatization will be merged or eliminated. Although the BIM ecosystem in China is far from being formed, the profits of large design units and construction enterprises are more than those of small enterprises, and in tandem with the increase of application rate [66]. When information and communication technology (ICT) is fully applied throughout the project life cycle, the sustainable development of the AEC industry can be achieved. The fourth stage of the ecosystem is re-innovation or extinction. If it is re-innovation, new innovation points will emerge, and the ecosystem will evolve around this new innovation point to form a new ecosystem [31]. In the final stage, the loose policy environment and the accelerated spread of new technologies will lead to further improvement of the ecosystem [31]. Based on the BIM platform, the pioneer enterprises will gain more market competitive advantages.

\section{Population size}

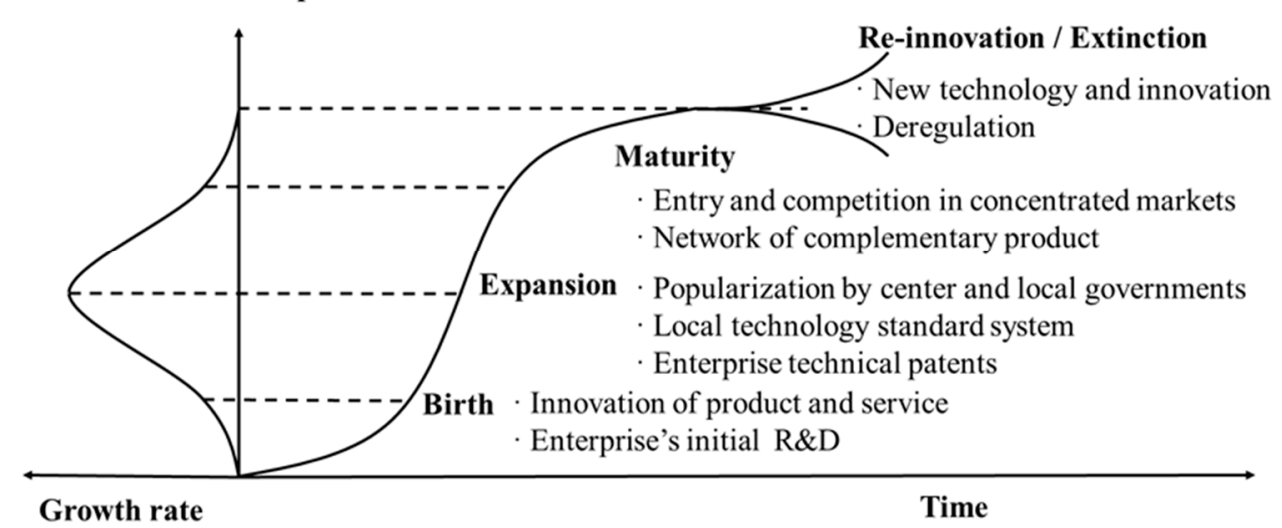

Figure 4. Cultivation path of a BIM ecosystem. 


\subsection{Case Description: Cultivation of a BIM Ecosystem in Shanghai}

China's construction industrialization and informatization is still in its infancy and has not yet formed a self-organizing ecosystem and efficient operation system. As a leading city in China to promote BIM technology, Shanghai was taken as a case study to illustrate the cultivation process of a BIM ecosystem.

Phase 1: The birth of a BIM ecosystem

BIM research in China first appeared in 1995. Initially, it kept a slow pace and mainly focused on the technological issues. In 2011, the MOHURD issued the first document to promote the building informatization reform from the policy perspective. In spite of the potential advantages of BIM, its implementation frequently involves a variety of technical and organizational barriers which may significantly influence the intentions of enterprises to use BIM. According to the report on the application of BIM in China's construction industry [67], 87\% of the respondents said they had heard of BIM, but $61 \%$ of them had never used it. Due to the lack of BIM talents and enterprises' motivation for implementing BIM, BIM had not been widely used. One of the key benefits that are highly recognized by users is clash detection, but only $6 \%$ of respondents have experience in this area. Although Shanghai takes the lead in the promotion of the BIM concept, it is still in the cognitive stage.

Phase 2: The expansion of a BIM ecosystem

One of the developing tasks at the second stage is the policy formulation. In June 2015, the Shanghai housing and urban-rural construction commission issued the Shanghai BIM guide (2015), which is the first regional standard that describes in detail the operational procedures, requirements, and expected results of $23 \mathrm{BIM}$ application items in life-cycle management. In order to meet the actual needs of the BIM implementation and to make the guide more operational, the second version of the guide was revised in 2017. Overall, by the end of 2016, the BIM policy and standard system in Shanghai has basically formed. In 2017, the establishment of the multilevel education and training system, the policy and standard system, and the supporting environment for BIM application was forming a more mature market. In May 2018, the Commission also promulgated the "Evaluation criteria for BIM application in affordable housing projects in Shanghai" to change the mode of government supervision.

The application of BIM technology is gradually being promoted in Shanghai. From September 2015 to June 2016, more than 60 BIM-based projects were selected as pilot projects in 5 batches, including hospitals, schools, affordable housing, rail transit, bridges (tunnels), and other aspects. The Shanghai World Expo Museum project, as the first pilot project, started in December 2013 and ended in 2016, providing valuable practical experience on the construction of the $3 \mathrm{D}$ collaboration platform and life-cycle management. Since 2017, the government projects that have invested more than $\$ 100$ million or have a single building area of more than 20,000 square meters (hereinafter referred to as "above the scale") must use BIM technology, and the society-invested ones are encouraged to use BIM. According to the statistics of BIM projects in Shanghai (see Figure 5), the number of BIM projects grows slowly first and then a bit quicker. Besides, the application rate of BIM projects that are "above the scale" increased from $29 \%$ to $88 \%$, but the overall application rate only reached $12 \%$ in 2017 , far below the goal of the first phase. In addition, it is designed that by 2020 BIM will be fully applied in the planning, design, and construction phases to achieve a goal of reducing project costs by $10 \%$ and construction periods by $5 \%$. Overall, Shanghai's BIM ecosystem is still in the immature phase, but gradually stepping to the rapidly developing stage, where Shanghai has made great efforts in terms of the formulation of standards, the implementation of pilot projects and financial support, and learned from big government-invested projects. 


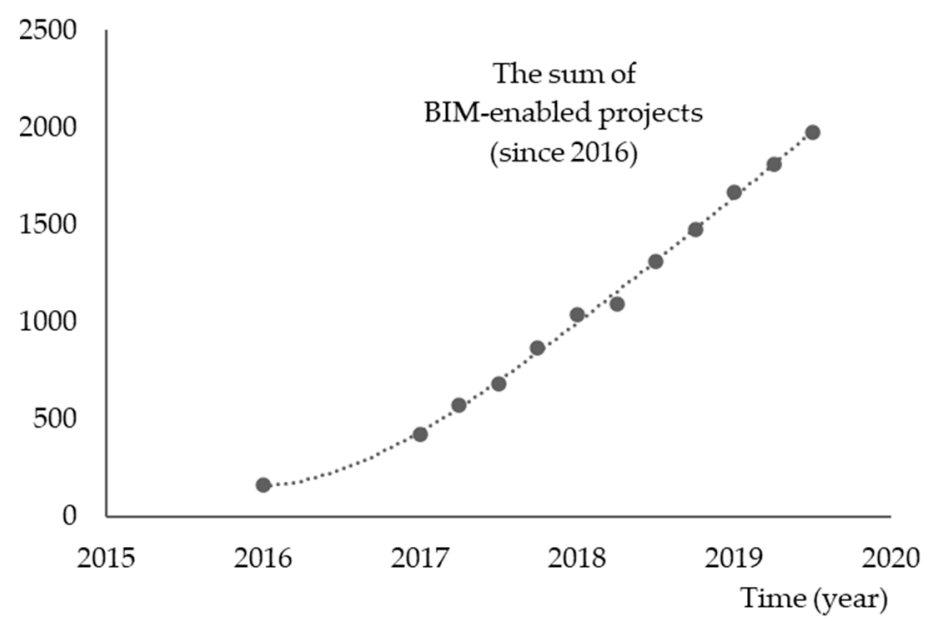

Figure 5. The number of BIM-based projects in Shanghai (since 2016).

Phase 3: The maturity of a BIM ecosystem

The periodic change of a BIM ecosystem is the result of the interaction of enterprises and environment. As the supporting environment in Shanghai matures, the government's role in promoting BIM would become less important, but the profit-seeking nature of enterprises would make them carry out information reform spontaneously to enhance the core competitiveness. The structure of a BIM ecosystem and its communities would become more fixed: large enterprises that take the lead in completing the reform of building informatization may form a monopoly position, while those lagging ones may face a survival crisis. Under the influence of technological, economic, and social environments, the enterprises' transformation to building informatization would be completed in this stage, partly reflected in the stable number of enterprises with information technology.

Phase 4: The re-innovation/extinction of a BIM-based innovation ecosystem

Enterprises also need to constantly discover the value behind BIM and niche markets. Trends like the emergence of new technology and diffusion of policy are predicted to increase the rate of enterprises' transformation and would give them a competitive advantage over the former winner who may fail to keep up with technological progress. As stage three emerges into the next stage, these interdependent but complementary actors would cooperate, compete, and co-evolve around the new innovation, starting a new round of evolution of the established ecosystem or creating an alternative ecosystem.

\section{Implications}

According to the cultivation path of the BIM ecosystem shown in Figure 4, the current development status of the BIM ecosystem in Shanghai is stepping into the early stage of the second phase, but the application rate of BIM in Shanghai is still at an inferior level. There is a long way to go before the BIM-based project network in China transforms to be a self-updating, self-organizing, and highly efficient ecosystem. Measures should be taken step by step from the following aspects.

Firstly, from the analysis of the structure of the BIM ecosystem, it can be seen that the most important factor influencing the formation of the BIM ecosystem comes from the market. Therefore, the government should implement flexible and diverse policies at an early stage, including pilot projects, financial support, and other preferential policies, promote innovation to benefit enterprises, and encourage enterprises to apply BIM to gain more practical experience. At the same time, in order to promote the construction of a BIM ecosystem, the government and enterprises should increase their investment in R\&D at the initial stage, including the construction of hardware facilities and the training 
of technical personnel. In particular, it is necessary to enhance the core capability of the BIM platform from a technical level to improve the quality of BIM-related products and services.

Secondly, according to the interviewees, many project participants build their own 3D models and do not communicate with each other, which causes a lot of resource waste. The government should help establish a support system to attract more outstanding enterprises to share information through the BIM platform. The support system includes technical standards, application specifications, and user guides. Its application scope covers the entire industry chain and the entire project life cycle.

Thirdly, all the interviewees agreed that the application of BIM to the whole life cycle of a project will maximize the effectiveness of BIM, which will contribute to the formation of the BIM ecosystem and promote the sustainability of the AEC industry. This requires a collaborative effort from all participants in the basic structure of the BIM ecosystem to sustain and cultivate a healthy and sustainable ecosystem, and the government should pay attention to the "networking" practice in the field of engineering projects and take measures to encourage the participants to collaborate. Participants in the networked practices should depend on each other for mutual benefit and co-create value that cannot be achieved by individual firms.

Fourthly, the core layer of the BIM ecosystem is the BIM platform, which can add the analysis module for sustainability assessment. As recommended by Chong, Lee, and Wang [8], the new or revised BIM standards and guidelines should include a set of requirements on the BIM tools to comply with a standard sustainability assessment. Relevant techniques, energy simulation software, and life-cycle assessment (LCA) tools should be integrated into the BIM platform to access the sustainability of building materials and energy consumption in the projects.

\section{Conclusions}

As a catalyst for sustainable development in the AEC industry, BIM not only brings technical benefits to the AEC industry, but changes the innovation paradigm of the AEC industry towards an innovation ecosystem. However, the theorizing of a BIM-based innovation ecosystem is still in its infancy, and in-depth studies from emerging economy are insufficient. This article contributes to innovation ecosystem theory by exploring the structure of the BIM ecosystem and deriving its cultivation path. The BIM ecosystem is composed of internal systems (BIM platforms and project stakeholders) and external supporting environments (technology, economy and society). The platform is the core of the BIM ecosystem, and each component of the system plays the roles of information producer, information consumer, and information decomposer, respectively. Based on the BIM platform, participants interact in a flexible, networked, and loosely coupled manner, which enables the flow of information and complementary resources across organizational boundaries, and hence ecosystem actors are co-evolving and continuously adapting to the external environment to survive and gain sustainable development. Factors such as policy, technology, and market demand affect the external environment and ultimately affect the evolution of the ecosystem to the next stage.

Mapping the cultivation path is the best way to determine whether the realistic performance expectations have been set for the innovation ecosystem [65]. This study derives the cultivation path of the BIM ecosystem for the long-term sustainability development goals. These goals include resource and energy conservation, whole life cycle, increased productivity, and others. Each stage of the BIM ecosystem has different characteristics and development tasks in terms of technology development and organizational management. With the ups and downs of the cultivation path, the structure of the BIM ecosystem will be adjusted accordingly. In the first stage, as the core layer of the ecosystem, BIM technology is continuously developed and improved, and its application scope is gradually expanded to the whole life cycle of construction projects. Then, with support from the government, the development of technical standards, application specifications, and user guides push the evolution of the BIM ecosystem to the second stage. This stage is mainly the integration of project participants and BIM technology. The transformation of BIM from technology to collaborative platforms is conducive to improving the application environment of the ecosystem. In the third stage, the spontaneous 
market adjustment and the formation of complementary networks between enterprises promoted the formation of the ecosystem structure. The fourth stage is the re-innovation or decay of the ecosystem, which is characterized by the emergence of new technologies, new innovations, or the deregulation of government regulation, thereby overturning the original structure. The challenge at this stage is to constantly update products and upgrade services, otherwise the ecosystem will face decline. The results show that the interdependent and symbiotic structural relationships among BIM ecosystem participants are formed under the influence of internal and external environments. This relationship structure supports the cultivation path of the birth, expansion, maturation, and reinvention of a BIM ecosystem.

One limitation of our study was that this study is a single exploratory case study from China's experiences. Although China's experiences can be extended to other emerging economies, the building and cultivation of the BIM ecosystem in other countries may show different patterns due to different national conditions. From this background, future research can focus on discussion of BIM ecosystems in different countries and regions, comparing and analyzing the impacts of different national and cultural backgrounds, the current state of the AEC industry, and the level of technological development on the construction and cultivation of BIM ecosystems. Another limitation is that the interviewees come from several different fields, such as civil aviation, transportation, housing construction, etc., which are currently developing standards and specifications for BIM applications appropriate to their fields, but our study does not differentiate between them. Future research could consider the distinction between these industry sectors.

Author Contributions: Conceptualization, Y.Y.; methodology, Y.Y.; data curation, Y.Y.; formal analysis, Y.Y. and Y.Z.; investigation, Y.Y. and Y.Z.; project administration, Y.Y.; supervision, H.X.; writing-original draft, Y.Y. and Y.Z.; writing-review and editing, Y.Y. and Y.Z.; funding acquisition, Y.Y. and H.X. All authors have read and agreed to the published version of the manuscript.

Funding: This research was supported by the National Natural Science Foundation of China (Grant No. 71673240 and 71772163), Zhejiang Provincial Natural Science Foundation of China (Grant No. LY16G020009 and LY17G020024), Guangzhou Philosophy and Social Science Foundation (Grant No.2020GZYB94).

Conflicts of Interest: The authors declare no conflict of interest.

\section{References}

1. Roufechaei, K.M.; Bakar, A.H.A.; Tabassi, A.A. Energy-efficient design for sustainable housing development. J. Clean. Prod. 2014, 65, 380-388. [CrossRef]

2. Becerik-Gerber, B.; Kensek, K. Building information modeling in architecture, engineering, and construction: Emerging research directions and trends. J. Prof. Issues Eng. Ed. Pract. 2010, 136, 139-147. [CrossRef]

3. Teng, Y.; Mao, C.; Liu, G.; Wang, X. Analysis of stakeholder relationships in the industry chain of industrialized building in China. J. Clean. Prod. 2017, 152, 387-398. [CrossRef]

4. Aziz, N.D.; Nawawi, A.H.; Ariff, N.R.M. ICT evolution in facilities management (FM): Building information modelling (BIM) as the latest technology. Procedia Soc. Behav. Sci. 2016, 234, 363-371. [CrossRef]

5. Chong, H.Y.; Lee, C.Y.; Wang, X. A mixed review of the adoption of building information modelling (BIM) for sustainability. J. Clean. Prod. 2017, 142, 4114-4126. [CrossRef]

6. Elmualim, A.; Gilder, J. BIM: Innovation in design management, influence and challenges of implementation. Architect. Eng. Des. Manag. 2014, 10, 183-199. [CrossRef]

7. McGraw Hill Construction. Prefabrication and Modularization: Increasing Productivity in the Construction Industry; Smart Market Report: Bedford, TX, USA, 2011.

8. Azhar, S.; Khalfan, M.; Maqsood, T. Building information modelling (BIM): Now and beyond. Aust. J. Constr. Econ. Build. 2012, 12, 15-28. [CrossRef]

9. Zhang, L.; Chu, Z.; Song, H. Understanding the relation between BIM application behavior and sustainable construction: A case study in China. Sustainability 2020, 12, 306. [CrossRef]

10. Yuan, H.; Yang, Y.; Xue, X. Promoting owners' BIM adoption behaviors to achieve sustainable project management. Sustainability 2019, 11, 3905. [CrossRef] 
11. Hetemi, E.; Ordieres-Meré, J.; Nuur, C. An institutional approach to digitalization in sustainability-oriented infrastructure projects: The limits of the building information model. Sustainability 2020, 12, 3893. [CrossRef]

12. Aksenova, G.; Kiviniemi, A.; Kocaturk, T.; Lejeune, A. From Finnish AEC knowledge ecosystem to business ecosystem: Lessons learned from the national deployment of BIM. Constr. Manag. Econ. 2019, 37, 317-335. [CrossRef]

13. Chen, C.; Yang, L.; Tang, L.; Jiang, H. BIM-based design coordination for China's architecture, engineering and construction industry. WIT Trans. Built Environ. 2017, 169, 211-219.

14. Chen, C.; Tang, L.C.M.; Jin, Y. Development of 5D BIM-based management system for pre-fabricated construction in China. In Proceedings of the International Conference on Smart Infrastructure and Construction 2019 (ICSIC): Driving Data-Informed Decision-Making, Cambridge, UK, 8-10 July 2019; De Jong, M., Schooling, J., Viggiani, G., Eds.; ICE Publishing: London, UK, 2019; pp. 215-224.

15. Yang, Y.; Zhang, Y.; Huang, W.T.; Xie, H.; Chen, L.J.; Cai, C.Y. Knowledge mapping of building information modelling research-A visual analysis using CiteSpace. In Proceedings of the 22nd International Conference on Advancement of Construction Management and Real Estate, Melbourne, Victoria, Australia, 20-23 November 2017; Zou, P.X.W., Ed.; CRIOCM 2017 Organising Committee: Swinburne University of Technology: Melbourne, Australia, 2017; pp. 608-615.

16. Jin, R.; Zou, P.; Piroozfar, P.; Wood, H.; Yang, Y.; Yan, L.; Han, Y. A science mapping approach based review of construction safety research. Saf. Sci. 2019, 113, 285-297. [CrossRef]

17. He, Q.; Wang, G.; Luo, L.; Shi, Q.; Xie, J.; Meng, X. Mapping the managerial areas of building information modeling (BIM) using scientometric analysis. Int. J. Proj. Manag. 2017, 35, 670-685. [CrossRef]

18. Ghaffarianhoseini, A.; Tookey, J.; Ghaffarianhoseini, A.; Naismith, N.; Azhar, S.; Efimova, O.; Raahemifar, K. Building Information Modelling (BIM) uptake: Clear benefits, understanding its implementation, risks and challenges. Renew. Sustain. Energy Rev. 2017, 75, 1046-1053. [CrossRef]

19. Antwi-Afari, M.F.; Li, H.; Pärn, E.A.; Edwards, D.J. Critical success factors for implementing building information modelling (BIM): A longitudinal review. Autom. Constr. 2018, 91, 100-110. [CrossRef]

20. Doumbouya, L.; Gao, G.; Guan, C. Adoption of the building information modeling (BIM) for construction project effectiveness: The review of bim benefits. Neth. Int. Law Rev. 2016, 55, 3-32.

21. Walasek, D.; Barszcz, A. Analysis of the adoption rate of building information modeling [BIM] and its return on investment. Procedia Eng. 2017, 172, 1227-1234. [CrossRef]

22. Tsai, M.H.; Mom, M.; Hsieh, S.H. Developing critical success factors for the assessment of BIM technology adoption: Part I. Methodology and survey. J. Chin. Inst. Eng. 2014, 37, 845-858. [CrossRef]

23. Eadie, R.; Browne, M.; Odeyinka, H.; McKeown, C.; McNiff, S. BIM implementation throughout the UK construction project lifecycle: An analysis. Autom. Constr. 2013, 36, 145-151. [CrossRef]

24. Luth, G.P.; Schorer, A.; Turkan, Y. Lessons from Using BIM to Increase Design-Construction Integration. Pract. Period. Struct. Des. Constr. 2014, 19, 103-110. [CrossRef]

25. Cao, D.; Li, H.; Wang, G.; Huang, T. Identifying and contextualising the motivations for BIM implementation in construction projects: An empirical study in China. Int. J. Proj. Manag. 2017, 35, 658-669. [CrossRef]

26. Gu, N.; Singh, V.; London, K. BIM ecosystem: The coevolution of products, processes, and people. In Building Information Modeling: BIM in Current and Future Practice; John Wiley \& Sons: Hoboken, NJ, USA, 2015; pp. 197-210.

27. Moore, J.F. Predators and prey: A new ecology of competition. Harv. Bus. Rev. 1993, 71, 75-86. [PubMed]

28. Adner, R.; Kapoor, R. Innovation ecosystems and the pace of substitution: Re-examining technology S-curves. Strateg. Manag. J. 2016, 37, 625-648. [CrossRef]

29. Clarysse, B.; Wright, M.; Bruneel, J.; Mahajan, A. Creating value in ecosystems: Crossing the chasm between knowledge and business ecosystems. Res. Policy 2014, 43, 1164-1176. [CrossRef]

30. Pulkka, L.; Ristimäki, M.; Rajakallio, K.; Junnila, S. Applicability and benefits of the ecosystem concept in the construction industry. Constr. Manag. Econ. 2016, 34, 129-144. [CrossRef]

31. Moore, J.F. The Death of Competition: Leadership and Strategy in the Age of Business Ecosystems; HarperBusiness: New York, NY, USA, 1996.

32. Singh, V. BIM ecosystem research: What, why and how? framing the directions for a holistic view of BIM. In Product Lifecycle Management for Digital Transformation of Industries; Harik, R., Rivest, L., Bernard, A., Eynard, B., Bouras, A., Eds.; Springer: Cham, Switzerland, 2016; Volume 492. 
33. Sant'Ana, T.D.; Bermejo, P.H.; Moreira, M.F.; Souza, W.V. The structure of an innovation ecosystem: Foundations for future research. Manag. Decis. 2020. [CrossRef]

34. McGraw Hill Construction. The Business Value of BIM for Construction in Major Global Markets: How Contractors around the World are Driving Innovation with Building Information Modeling; McGraw Hill Construction: Manhattan, NY, USA, 2014.

35. Liu, Y.; Zeng, N.S.; Xu, B. Research on the concept and framework of building information modeling ecosystem. In Proceedings of the 2014 International Conference on Management Science \& Engineering 21th Annual Conference Proceedings, Helsinki, Finland, 17-19 August 2014; pp. 1799-1805.

36. McCracken, G. The Long Interview; Sage Publications: Newbury Park, CA, USA, 1998.

37. SMCHURDM; SBTAJCO. Shanghai BIM Technology Application E Development Reports (2016); Shanghai Housing and Urban-Rural Construction Administration Commission: Shanghai, China, 2016.

38. SMCHURDM; SBTAJCO. Shanghai BIM Technology Application E Development Reports (2017). Available online: http://www.shbimcenter.org/documents/20552/0/2017\%E4\%B8\%8A\%E6\%B5\%B7\%E5\%B8\%82\%E5\%BB\% BA $\%$ E7\%AD $\% 91 \% \mathrm{E} 4 \%$ BF\%A1\%E6\%81\%AF\%E6\%A8\%A1\%E5\%9E\%8B\%E6\%8A \%80\%E6\%9C\%AF\%E5 \%BA $\% 94 \%$ E7\%94\%A8\%E4\%B8\%8E\%E5\%8F\%91\%E5\%B1\%95\%E6\%8A\%A5\%E5\%91\%8A.pdf/83792ba0-d3 29-4661-b31e-7b4bced2ad6c (accessed on 21 March 2019).

39. SMCHURDM; SBTAJCO. Shanghai BIM Technology Application E Development Reports (2018). Available online: http://www.shbimcenter.org/documents/20552/212684/2018\%E4\%B8\%8A\%E6\%B5\%B7\%E5\%BB\%BA\%E7\%

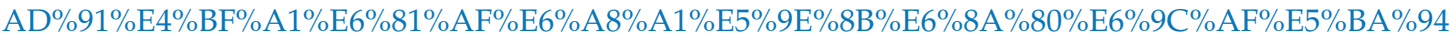
\%E7\%94\%A8\%E4\%B8\%8E\%E5\%8F\%91\%E5\%B1\%95\%E6\%8A\%A5\%E5\%91\%8Anew.pdf/77f2298c-1ddd4876-8b75-986e06057a5d (accessed on 21 March 2019).

40. SMCHURDM; SBTAJCO. Shanghai BIM Technology Application E Development Reports (2019). Available online: https://www.shgbc.org/Attach/Attaches/201905/201905131038228857.pdf (accessed on 26 May 2019).

41. MOHURD. The 2011-2015 Outline for the Information Development of the Construction Industry. In Jianzhi [2011] 67; 2011. Available online: http://www.mohurd.gov.cn/wjfb/201105/t20110517_203420.html (accessed on 12 September 2018).

42. MOHURD; AQSIQ. Unified Standard for Building Information Model Application (GB/T51212-2016); China Architecture \& Building Press: Beijing, China, 2016.

43. MOHURD. Standard for Classification and Coding of Building Information Model (GB/T51269-2017); China Architecture \& Building Press: Beijing, China, 2017.

44. MOHURD. Standard for Storage of Building Information Model; Under Approval.

45. MOHURD. Application Standard for Manufacturing Industry Design Information Model (GB/T51362-2019); China Planning Press: Beijing, China, 2019.

46. MOHURD. Standard for Design Delivery of Building Information Modeling (GB/T 51301-2018); China Architecture \& Building Press: Beijing, China, 2018.

47. MOHURD. Standard for Building Information Modelling in Construction (GB/T 51235-2017); China Architecture \& Building Press: Beijing, China, 2017.

48. MOHURD. Presentation Standard for Building Information Modeling (JGJ/T448-2018); China Architecture \& Building Press: Beijing, China, 2018.

49. Ridder, H.G. The theory contribution of case study research designs. Bus. Res. 2017, 10, 281-305. [CrossRef]

50. Ding, L.; Wu, J. Innovation ecosystem of CNG vehicles: A case study of its cultivation and characteristics in Sichuan, China. Sustainability 2018, 10, 39. [CrossRef]

51. Glaser, B.G.; Strauss, A.L. The Discovery of Grounded Theory: Strategies for Qualitative Research; Routledge: Abingdon, UK, 2017.

52. Taylor, J.E.; Bernstein, P. Paradigm trajectories of building information modeling practice in project networks. J. Manag. Eng. 2009, 25, 69-76. [CrossRef]

53. Holmström, J.; Singh, V.; Främling, K. BIM as infrastructure in a Finnish HVAC actor network: Enabling adoption, reuse, and recombination over a building life cycle and between projects. J. Manag. Eng. 2015, 31, A4014006. [CrossRef]

54. Tansley, A.G. The use and abuse of vegetational concepts and terms. Ecol. Environ. Sci. 1935, 16, $284-307$. [CrossRef]

55. Adner, R. Ecosystem as structure: An actionable construct for strategy. J. Manag. 2017, 43, 39-58. [CrossRef] 
56. Succar, B. Building information modelling framework: A research and delivery foundation for industry stakeholders. Autom. Constr. 2009, 18, 357-375. [CrossRef]

57. Succar, B.; Kassem, M. Macro-BIM adoption: Conceptual structures. Autom. Constr. 2015, 57, 64-79. [CrossRef]

58. Arthur, S.; Li, H.; Lark, R. A Collaborative Unified Computing Platform for Building Information Modelling (BIM). In Proceedings of the Working Conference on Virtual Enterprises, Cham, Switzerland, 18-20 September 2017; Springer International Publishing: Cham, Switzerland, 2017; pp. 63-73.

59. Moore, D.R.; Dainty, A.R.J. Integrated project teams' performance in managing unexpected change events. Team Perform. Manag. 1999, 5, 212-222. [CrossRef]

60. Gu, N.; London, K. Understanding and facilitating BIM adoption in the AEC industry. Autom. Constr. 2010, 19, 988-999. [CrossRef]

61. Peansupap, V.; Walker, D.H.T. Factors enabling information and communication technology diffusion and actual implementation in construction organisations. ITcon 2005, 10, 193-218.

62. Taylor, J.E.; Levitt, R.E. Understanding and managing systemic innovation in project-based industries. In Innovations: Project Management Research; Project Management Institute: Newtown Square, PA, USA, 2004; pp. 83-99.

63. Dubois, A.; Gadde, L.E. The construction industry as a loosely coupled system: Implications for productivity and innovation. Constr. Manag. Econ. 2002, 20, 621-631. [CrossRef]

64. Tsinghua University BIM Task Group. Research on Chinese Building Information Modeling Standard Framework; China Architecture \& Building Press: Beijing, China, 2011.

65. Adner, R. Match your innovation strategy to your innovation ecosystem. Harv. Bus. Rev. 2006, 84, 98-107.

66. Dodg Data \& Analytics. The Business Value of BIM in China; Dodge Data and Analytics: Bedford, MA, USA, 2015.

67. He, G. The Report on the Application of BIM in China's Construction Industry (2011); China Real Estate Association-Commercial Real Estate Professional Committee: Beijing, China, 2011.

(C) 2020 by the authors. Licensee MDPI, Basel, Switzerland. This article is an open access article distributed under the terms and conditions of the Creative Commons Attribution (CC BY) license (http://creativecommons.org/licenses/by/4.0/). 